\title{
Study of the chemical composition of essential oils and floral waters of Cymbopogon citratus (DC.) Stapf (Poaceae) from Senegal
}

\author{
Serigne Mbacké DIOP ${ }^{1,2^{*}}$, Momar Talla GUÈYE ${ }^{1}$, Ibrahima NDIAYE ${ }^{2}$, \\ Michel Bakar DIOP ${ }^{3}$, El Hadji Barka NDIAYE ${ }^{1,2}$, Abdoulaye THIAM ${ }^{1,2}$, \\ Marie-Laure FAUCONNIER ${ }^{4}$ and Georges LOGNAY ${ }^{5}$ \\ ${ }^{1}$ Laboratoire des Analyses Phytosanitaires, Institut de Technologie Alimentaire, \\ BP 2765 Hann-Dakar, Sénégal. \\ ${ }^{2}$ Département de Chimie, Faculté des Sciences et Techniques, \\ Université Cheikh Anta Diop, BP 5005 Dakar, Sénégal. \\ ${ }^{3}$ UFR des Sciences Agronomiques, d'Aquaculture et de Technologie Alimentaire (S2ATA), \\ Université Gaston Berger BP 234 Saint Louis, Sénégal. \\ ${ }^{4}$ Chimie Générale et Organique, Département Agro-Bio-Chem, Gembloux Agro-Bio Tech, \\ Université de Liège 2, Passage des Déportés-5030 Gembloux, Belgique. \\ ${ }^{5}$ Chimie Analytique, Département Agro-Bio-Chem, Gembloux Agro-Bio Tech, \\ Université de Liège 2, Passage des Déportés-5030 Gembloux, Belgique. \\ *Corresponding author,E-mail: serigneami@hotmail.fr; Tel: 00221779738173.
}

\section{ACKNOWLEDGMENTS}

This work was supported by the project «WBI-Sénégal n²: Production d'huiles essentielles à partir de plantes locales: expérimentation, adaptation et diffusion de technologies » and the authors wish to thank WBI (Wallonie Bruxelles Internationale, Belgium) for providing funds to conduct this research.

\begin{abstract}
This work aimed to study the chemical composition of essential oils and floral waters of Cymbopogon citratus (DC.) Stapf (Poaceae) from Senegal. The plants were collected in two different localities, Dakar and Kaolack. The extracts were obtained by steam distillation from both fresh and dried plants and analyses carried out by GC/FID and GC/MS. Oils from Dakar were dominated by geranial which represented 46.0-43.9\%, neral $31.8-31.0 \%$, myrcene $10.8-11.7 \%$ and geraniol $2.7-4.2 \%$ in the fresh and dried plants, respectively. Their floral waters contained mainly $44.6-41.4 \%$ geranial, $39.7-35.6 \%$ neral and $8.8-13.2 \%$ geraniol. The oils from Kaolack were characterized by geranial which constituted $49.5-44.5 \%$, neral $33.3-31.2 \%$, myrcene $7.2-9.6 \%$ and geraniol $4.3-6.1 \%$ in the fresh and dried plants, respectively. In their floral waters, it is identified 42.8 $33.6 \%$ geranial, $38.4-27.6 \%$ neral and $12.5-24.5 \%$ geraniol. This original study revealed that both oils and floral waters of $C$. citratus from Senegal are characterized by geranial and neral whose repellent properties against mosquitoes are known.
\end{abstract}

(C) 2017 International Formulae Group. All rights reserved.

Keywords: Cymbopogon citratus, essential oils, floral waters, geranial, neral. 


\section{INTRODUCTION}

There is a large biodiversity of aromatic plants in Senegal. Among them, basil, lemongrass, eucalyptus and mint represent four very interesting sources. These plants that contain essential oil are used in many fields such as food, agriculture, perfumery and medicine. But most of them have not yet been investigated. In Senegal, Cymbopogon citratus is known for its repellent properties against anopheles mosquitoes which are vectors of Malaria that kills many children in sub-saharan Africa. Recent WHO epidemiological profile in Senegal reports more than 1 case per 1000 population (WHO, 2015). Local intervention policies and strategies include larval control, diagnosis, treatments and surveillance financially supported by Government, Global fund and USAID/PMI. It is also reported that C. citratus showed insecticidal, antifungicidal, antiinflammatory, antibacterial and antioxidant activities (Naik et al., 2010; Francisco et al., 2013; Avoseh et al., 2015; Bossou et al., 2015; Briones et al., 2015; Fadli et al., 2016). Efficacy of $C$. citratus is indeed linked to its biochemical composition. In many studies, geranial, neral and myrcene were identified as major constituents of $C$. citratus oils (Bassolé et al., 2011; Costa et al., 2011; Kpoviessi et al., 2014). In addition, the chemical composition of essential oils of $C$. citratus may vary according to the drying methods (Hanaa et al., 2012).

Ongoing researches revealed that endemic plants in Senegal can be valorized for essential oil production. Within an international project designed to promote the production of essential oils in Senegal, several endemic plants among which $C$. citratus have been selected and investigated for their potential uses. The main issue of this global project is to produce bioextracts of plants which can be used in food, pharmaceutical products and for grain protection (Guèye, 2012; Ngom et al., 2014). Although pertinent for the development of local productions, this issue demands previous scientific attention.
Indeed, before starting pilote production, it has been logically suggested to study selected samples of plants in order to characterize their essential oils and to make some comparison with commercial products. For that purpose, laboratory scale hydrodistillations have been undertaken followed by chromatographic/ spectrometric characterization of essential oil constituents. The main constraint with essential oils is their low yield, less than $2 \%$ (Smadja, 2009). However, floral waters that constituted their by-products are produced in high volume and can also be valorized for both food and pharmaceutical applications. Study from literature showed that essential oils and floral waters are characterized by the same major components (Sutour, 2010; Diop et al., 2016). In order to locally develop valuable products that offer good repellency properties, this original work has been carried out on Senegalese C. citratus. The aim of this present work is to study the chemical composition of essential oils (EOs) and floral waters (FWs) of C. citratus from Dakar and Kaolack regions, Senegal.

\section{MATERIALS AND METHODS}

Plant material and essential oils extraction Cymbopogon citratus (DC.) Stapf (Poaceae) plants were collected in 2015 in two regions of Senegal: Dakar and Kaolack. After identification, specimens $\left(\mathrm{CD}_{1}\right.$ and $\left.\mathrm{CK}_{1}\right)$ were deposited in the herbarium of the "Institut Fondamental d'Afrique Noire de l'Université Cheikh Anta Diop de Dakar". Essential oils and floral waters were obtained by submitting separately $100 \mathrm{~g}$ of both fresh $(\mathrm{F})$ and dried (D) plants (let at room temperature, $18-27{ }^{\circ} \mathrm{C}$ for 7 days in the shade) to steam distillation for 30 min using a Clevenger-type apparatus. Oils and floral waters were stored in the refrigerator (at $4{ }^{\circ} \mathrm{C}$ ) in amber vials until analysis.

\section{Essential oils characterization}

Essential oils and floral waters samples were subjected to gas chromatography. Essential oils solutions: $10 \mathrm{mg} / 10 \mathrm{ml}$ in $n$ - 
hexane were prepared and diluted four times before analysis. Organic substances from floral waters were extracted by liquid-liquid with $n$-hexane $(10 / 2, \mathrm{v} / \mathrm{v}) .1 \mu \mathrm{l}$ of these both solutions were injected by analysis. The following chromatographic conditions were used: injector (Splitless mode) and detector temperatures: $280{ }^{\circ} \mathrm{C}$ and $290{ }^{\circ} \mathrm{C}$, respectively; oven: initial temperature $40{ }^{\circ} \mathrm{C}$ (5 min), ramp of $8{ }^{\circ} \mathrm{C} / \mathrm{min}$ until final temperature $280{ }^{\circ} \mathrm{C} \quad(5 \mathrm{~min})$; carrier gas, helium at a constant rate set at $1.5 \mathrm{ml} / \mathrm{min}$; air and hydrogen flows: $350 \mathrm{ml} / \mathrm{min}$ and 35 $\mathrm{ml} / \mathrm{min}$, respectively. The column used was a fused silica capillary, Optima-5-MS-Accent (Macherey-Nagel, Düren-Germany), 5\% phenyl-95\% methylsiloxane ( $30 \mathrm{~m} \times 0.25 \mathrm{~mm}$, $0.25 \mu \mathrm{m}$ film thickness).

GC/FID-Trace Ultra GC from Thermo Electron Corporation (Interscience LouvainLa-Neuve, Belgium) fitted with a flame ionization detector was used for determination of the proportion (\%) of each constituent.

GC/MS-Identification of components was carried out on a mass spectrometer from Agilent 5973 Network Mass Selective Detector Quadrupole coupled to a gas chromatograph Agilent 6890N (G1530N), USA. Mass spectra were recorded at $70 \mathrm{eV}$ and the mass scanned range was from 50 to $550 \mathrm{amu}$. The mass spectra were compared to those from a computerized database (Wiley $275 \mathrm{~L})$ and those given in the literature (Joulain and König, 1998; Adams, 2001). Pure compounds confirmed the identification of the major constituents.

\section{RESULTS}

The yields of the essential oils extraction were of 0.42 and $0.42 \%$ (Dakar) and 0.55 and $0.48 \%$ (Kaolack) in the fresh and dried plants, respectively. Oils and floral waters were rich in monoterpenes (Tables 1 and 2). The total content of oxygenated monoterpenes of FWs were higher than those of EOs, whereas monoterpene hydrocarbons were more abundant in EOs. Oxygenated monoterpenes represented 87.0 and $85.8 \%$ (EOs) and 98.1 and $98.0 \%$ (FWs) for Dakar and constituted 91.8 and $87.1 \%$ (EOs) and 97.8 and $95.1 \%$ (FWs) for Kaolack in the fresh and dried plants, respectively. In Dakar, oils contained 11.4 and $12.5 \%$ and floral waters 1.3 and $1.2 \%$ of monoterpene hydrocarbons. The latter were of 7.5 and $10.6 \%$ (EOs) and 1.3 and $2.3 \%$ (FWs) for Kaolack in the fresh and dried plants, respectively. Sesquiterpenes represented less than $1.0 \%$ for both oils and floral waters. The prominent components identified in the EOs of Cymbopogon citratus from Dakar and Kaolack were the following four acyclic monoterpenes: geranial, neral, myrcene and geraniol. Floral waters were dominated by geranial, neral, and geraniol; they contained lower proportions of myrcene than essential oils. In EOs from Dakar, geranial represented 46.0 (F) and $43.9 \%$ (D) and neral 31.8 (F) and $31.0 \%$ (D). They were followed by myrcene 10.8 and $11.7 \%$ and geraniol 2.7 and $4.2 \%$ in the fresh and dried plants, respectively. FWs from Dakar contained mainly $44.6(\mathrm{~F})$ and $41.4 \%$ (D) geranial, 39.7 (F) and 35.6\% (D) neral and 8.8 (F) and $13.2 \%$ (D) geraniol. The most important constituents of EOs from Kaolack were geranial which constituted 49.5 (F) and $44.5 \%$ (D) and neral 33.3 (F) and $31.2 \%$ (D). Myrcene with 7.2 (F) and 9.6\% (D) and geraniol 4.3 (F) and 6.1\% (D) were also obtained in these oils. In the FWs, it is identified 42.8 and $33.6 \%$ geranial, 38.4 and $27.6 \%$ neral and 12.5 and $24.5 \%$ geraniol in the fresh and dried plants, respectively. Other components were identified in lower rates. 6methyl-5-Hepten-2-one which was only 0.4 (F) and $0.9 \%$ (D) in oils from Dakar and Kaolack, represented 1.1 and 3.1\% (Dakar) and 1.3 and $4.2 \%$ (Kaolack) in floral waters from fresh and dried plants, respectively. Linalool, rosefuran epoxide, citronellol and geranyl acetate constituted less than $2.0 \%$ in both EOs and FWs. 
Table 1: Chemical composition of essential oils and floral waters of Cymbopogon citratus from Dakar.

\begin{tabular}{|c|c|c|c|c|c|}
\hline \multirow[b]{2}{*}{ Compounds } & \multirow[b]{2}{*}{$\begin{array}{l}\text { Retention } \\
\text { indices }\end{array}$} & \multicolumn{2}{|c|}{ Essential oils } & \multicolumn{2}{|c|}{ Floral waters } \\
\hline & & $\begin{array}{l}\text { Fresh } \\
\text { plants }\end{array}$ & $\begin{array}{c}7 \text { days of } \\
\text { drying }\end{array}$ & $\begin{array}{l}\text { Fresh } \\
\text { plants }\end{array}$ & $\begin{array}{c}7 \text { days of } \\
\text { drying }\end{array}$ \\
\hline 6-Methyl-5-hepten-2-one & 984 & 0.4 & 0.9 & 1.1 & 3.1 \\
\hline Myrcene & 990 & 10.8 & 11.7 & 0.5 & 0.6 \\
\hline$\alpha$-Phellandrene & 1008 & - & - & 0.1 & - \\
\hline para-Cymene & 1028 & - & 0.2 & 0.2 & 0.2 \\
\hline$(Z)-\beta$-Ocimene & 1037 & - & - & 0.1 & - \\
\hline$(E)-\beta$-Ocimene & 1047 & 0.2 & 0.3 & 0.1 & 0.3 \\
\hline 1-Methyl-4-isopropenylbenzene & 1090 & 0.1 & - & - & - \\
\hline Linalool & 1100 & 1.1 & 1.1 & 1.2 & 1.4 \\
\hline para-Mentha-1,5,8-triene & 1105 & - & - & 0.1 & - \\
\hline 4-Ethylnon-3-en-5-yne & 1113 & 0.1 & - & 0.1 & - \\
\hline trans, para-2,8-Menthadien-1-ol & 1118 & - & - & 0.1 & - \\
\hline 2,3-Dimethoxyphenol & 1127 & - & - & - & 0.1 \\
\hline allo-Ocimene & 1129 & 0.2 & 0.3 & - & - \\
\hline neo, allo-Ocimene & 1142 & - & - & 0.1 & 0.1 \\
\hline trans-Chtysantemal & 1144 & 0.3 & 0.3 & 0.2 & 0.1 \\
\hline Citronellal & 1154 & 0.3 & 0.5 & 0.2 & 0.2 \\
\hline Not identified & 1162 & 0.5 & 0.5 & - & - \\
\hline Rosefuran epoxide & 1180 & 1.4 & 1.4 & 0.2 & 0.2 \\
\hline Menthol & 1184 & 0.6 & - & - & - \\
\hline Isopulegone & 1187 & 0.1 & 0,1 & 0.3 & 0.3 \\
\hline Not identified & 1196 & 0.3 & 0.3 & - & - \\
\hline Not identified & 1205 & 0.2 & 0.2 & 0.4 & 0.4 \\
\hline 4,7-Dimethylbenzofuran & 1213 & - & 0.1 & 0.2 & 0.1 \\
\hline Citronellol & 1224 & 0.8 & 0.9 & 1.5 & 1.3 \\
\hline Neral & 1241 & 31.8 & 31.0 & 39.7 & 35.6 \\
\hline Geraniol & 1250 & 2.7 & 4.2 & 8.8 & 13.2 \\
\hline Geranial & 1270 & 46.0 & 43.9 & 44.6 & 41.4 \\
\hline Not identified & 1283 & 0.2 & - & - & - \\
\hline 2-Undecanone & 1291 & 0.9 & 0.6 & - & - \\
\hline 2-Methoxy-4-vinylphenol & 1313 & - & - & - & 0.3 \\
\hline Not identified & 1316 & - & - & - & 0.2 \\
\hline Neric acid & 1342 & 0.2 & 0.1 & 0.1 & - \\
\hline Piperitenone & 1350 & - & - & - & 0.8 \\
\hline Geranyl acetate & 1375 & 0.4 & 0.8 & - & - \\
\hline Eucarvone & 1422 & - & - & 0.1 & - \\
\hline (E)- $\beta$-Caryophyllene & 1437 & - & 0.1 & - & - \\
\hline trans- $\alpha$-Bergamotene & 1442 & - & 0.1 & - & - \\
\hline 2-Tridecanone & 1493 & 0.4 & 0.4 & - & - \\
\hline Not identified & 1544 & - & - & - & 0.1 \\
\hline Oxygenated monoterpenes & & 87.0 & 85.8 & 98.1 & 98.0 \\
\hline Monoterpenic hydrocarbons & & 11.4 & 12.5 & 1.3 & 1.2 \\
\hline Oxygenated sesquiterpenes & & 0.4 & 0.4 & $\mathbf{0 . 0}$ & 0.0 \\
\hline Sesquiterpenic hydrocarbons & & 0.0 & 0.2 & 0.0 & 0.0 \\
\hline Not identified & & 1.2 & 1.0 & 0.4 & 0.7 \\
\hline
\end{tabular}


Table 2: Chemical composition of essential oils and floral waters of Cymbopogon citratus from Kaolack.

\begin{tabular}{|c|c|c|c|c|c|}
\hline \multirow[b]{2}{*}{ Compounds } & \multirow[b]{2}{*}{$\begin{array}{c}\text { Retention } \\
\text { indices }\end{array}$} & \multicolumn{2}{|c|}{ Essential oils } & \multicolumn{2}{|c|}{ Floral waters } \\
\hline & & $\begin{array}{l}\text { Fresh } \\
\text { plants }\end{array}$ & $\begin{array}{c}7 \text { days of } \\
\text { drying }\end{array}$ & $\begin{array}{l}\text { Fresh } \\
\text { plants }\end{array}$ & $\begin{array}{c}7 \text { days of } \\
\text { drying }\end{array}$ \\
\hline 1-Octen-3-ol & 978 & - & 0.2 & - & - \\
\hline 6-Methyl-5-hepten-2-one & 984 & 0.4 & 0.9 & 1.3 & 4.2 \\
\hline Myrcene & 990 & 7.2 & 9.6 & 0.6 & 1.0 \\
\hline$\alpha$-Phellandrene & 1008 & - & - & 0.1 & 0.1 \\
\hline para-Cymene & 1028 & 0.1 & 0.3 & 0.2 & 0.1 \\
\hline$(Z)-\beta$-Ocimene & 1037 & - & - & 0.1 & 0.1 \\
\hline$E$ - $(\beta)$-Ocimene & 1047 & - & 0.3 & 0.2 & 0.8 \\
\hline trans-linalool oxide & 1075 & - & - & - & 0.1 \\
\hline Linalool & 1100 & - & 0.9 & 0.9 & 1.4 \\
\hline para-Mentha-1,5,8-triene & 1105 & - & - & - & 0.1 \\
\hline 4-Ethylnon-3-en-5-yne & 1113 & - & 0.1 & - & - \\
\hline trans, para-2,8-Menthadien-1-ol & 1118 & - & - & 0.1 & - \\
\hline 2,3-Dimethoxyphenol & 1127 & - & - & - & 0.1 \\
\hline allo-Ocimene & 1129 & 0.2 & 0.3 & - & 0.1 \\
\hline neo, allo-Ocimene & 1142 & - & - & 0.1 & - \\
\hline trans-Chtysantemal & 1144 & 0.3 & 0.3 & 0.1 & - \\
\hline Citronellal & 1154 & 0.2 & 0.4 & - & 0.2 \\
\hline Not identified & 1162 & 0.2 & 0.4 & - & - \\
\hline Not identified & 1165 & - & - & - & 0.2 \\
\hline Rosefuran epoxide & 1180 & 1.4 & 1.3 & 0.2 & 0.1 \\
\hline Menthol & 1184 & 0.2 & - & - & - \\
\hline Isopulegone & 1187 & - & 0.1 & - & - \\
\hline Not identified & 1196 & - & - & 0.2 & 0.5 \\
\hline Not identified & 1205 & 0.2 & 0.2 & 0.5 & 0.4 \\
\hline 4,7-Dimethylbenzofuran & 1213 & - & - & 0.2 & 0.1 \\
\hline Citronellol & 1224 & 0.8 & 0.8 & 1.4 & 1.2 \\
\hline Neral & 1241 & 33.3 & 31.2 & 38.4 & 27.6 \\
\hline Geraniol & 1250 & 4.3 & 6.1 & 12.5 & 24.5 \\
\hline Geranial & 1270 & 49.5 & 44.5 & 42.8 & 33.6 \\
\hline Not identified & 1283 & 0.1 & 0.1 & - & - \\
\hline Not identified & 1289 & 0.1 & - & - & 0.1 \\
\hline 2-Undecanone & 1291 & 0.2 & - & - & - \\
\hline 2-Methoxy-4-vinylphenol & 1313 & - & - & - & 1.0 \\
\hline Neric acid & 1342 & 0.2 & 0.1 & 0.1 & - \\
\hline Piperitenone & 1350 & - & - & - & 2.0 \\
\hline Geranyl acetate & 1375 & 1.0 & 1.5 & - & - \\
\hline Eucarvone & 1422 & - & - & - & 0.1 \\
\hline (E)- $\beta$-Caryophyllene & 1437 & - & 0.1 & - & - \\
\hline trans- $\alpha$-Bergamotene & 1442 & - & 0.1 & - & 0.1 \\
\hline 2-Tridecanone & 1493 & 0.1 & 0.2 & - & - \\
\hline Not identified & 1544 & - & - & - & 0.2 \\
\hline Oxygenated monoterpenes & & 91.8 & 87.1 & 97.8 & 95.1 \\
\hline Monoterpenic hydrocarbons & & 7.5 & 10.6 & 1.3 & 2.3 \\
\hline Oxygenated sesquiterpenes & & 0.1 & 0.2 & 0.0 & 0.0 \\
\hline Sesquiterpenic hydrocarbons & & $\mathbf{0 . 0}$ & 0.2 & $\mathbf{0 . 0}$ & 0.1 \\
\hline Not identified & & 0.6 & 0.7 & 0.7 & 1.4 \\
\hline
\end{tabular}




\section{DISCUSSION}

Minor variations were noted in the yields after drying. Plants from Kaolack produced more essential oils than those from Dakar in both fresh and dried plants. Oils and floral waters were dominated by three oxygenated monoterpenes (geranial, neral and geraniol) and one monoterpenic hydrocarbon (myrcene). Depending on the origin, it is showed no important variations in the chemical composition of both oils and floral waters. Both isomers geranial and neral were the most representative compounds identified in oils and floral waters and they decreased after drying. EOs were higher in geranial and lower in neral than FWs in Dakar and Kaolack regions, except the content of neral in FWs of dried plants from Kaolack compared with their EOs. For geraniol, the proportions were more abundant in FWs than EOs and a strong increase of percentages was noted in dried plants compared to fresh plants. The most significant variation observed in the chemical compositions was myrcene, compound which represented 10.8 and $11.7 \%$ (Dakar) and 7.2 and $9.6 \%$ (Kaolack) in essential oils and identified only between 0.5 and $1.0 \%$ in floral waters. Geraniol that represented 8.8 and $13.2 \%$ (Dakar) and 12.5 and $24.5 \%$ (Kaolack) of the FWs from Senegal constituted also $7.1 \%$ in commercial oil of Cymbopogon citratus from Pranarom, Belgium (Ahmad and Viljoen, 2015). Geranial, neral and myrcene have been reported as major constituents of several essential oils of Cymbopogon citratus (Blanco et al., 2009; Bassolé et al., 2011; Costa et al., 2011; Hanaa et al., 2012; Kpoviessi et al., 2014). In these latter as in those from Senegal and FWs, geranial was the most abundant, followed by neral. These oils showed important biological properties. Costa et al. (2011) indicated the beneficial effects of C. citratus in the reducing of the blood cholesterol level. Kpoviessi et al. (2014) reported the antitrypanosomal and antiplasmodial activities of lemongrass oils. Floral waters from Senegal that were also characterized by geranial and neral may constitute an alternative to low yields of oils. The composition of oils and floral waters of C. citratus from Senegal is similar to those of the commercial oils from Aroma Zone (France) that contain mainly geranial $40.4 \%$, neral $37.1 \%$ and geraniol $8.4 \%$. In this work, the chemical composition of EOs and FWs of C. citratus from Senegal has been studied for the first time. Thus, the results showed the chemical profile of the extracts of this aromatic plant which are often used in this country without any information on their biochemical constituents that are responsible of the nutritional and therapeutic properties. Cymbopogon essential oil is generally recognized as a power repellent against anopheles. About this, Leal and Uchida (1998) revealed that both geranial and neral were responsible for the efficacy of $C$. citratus against mosquitoes. Ongoing study on the properties of the Senegalese EOs and FWs will provide useful information about their aromatic properties and their use to fight against malaria, one of the deadliest diseases in Africa. To do it, spray against mosquitoes can be formulated with $C$. citratus extracts. As such or microencapsulated with natural products (arabic-gelatin gum, oils of coconut, soybean or olive) that increase its efficacy, this product may play at least locally a key role in malaria prevention (Maia and Moore, 2011; Soonwera and Phasomkusolsil, 2015) but this approach needs further investigations. In alimentary field, floral waters can also be introduced within atomized products for tea and infusions. 


\section{Conclusion}

The present study is the first conducted on C. citratus from Senegal. The results revealed that the origin of the plants and the drying had minor effects on the chemical composition of the EOs and FWs. It is also showed that the EOs and FWs studied have the same major constituents. Indeed both geranial and neral were the prominent compounds of the extracts from Dakar and those from Kaolack. These compounds are known for their repellent properties against mosquitoes and could be used in the fight against malaria. Further researches could allow to study the biological properties of $C$. citratus from Senegal.

\section{COMPETING INTERESTS}

The authors declare that they have no competing interests.

\section{AUTHORS' CONTRIBUTIONS}

SMD made the extractions, carried out the analyzes and wrote the article; MTG supervised the extractions and participated on the writing of the article; IN supervised the extractions and participated on the writing of the article; MBD participated on the writing of the article; El HBN participated on the analyzes; AT participated on the extractions and the analyzes; M-LF provided the GC/MS apparatus and participated on the analyzes.

GL orientated the research, supervised the analyses and participated on the writing of the article.

\section{REFERENCES}

Adams RP. 2001. Identification of Essential Oil Components by Gas Chromatography/Quadrupole Mass Spectrometry. Allured Publishing Co: Carol Stream IL., USA.
Ahmad A, Viljoen A. 2015. The in vitro antimicrobial activity of Cymbopogon essential oil (lemongrass) and its interaction with silver ions. Phytomedicine, 22: 657-66. DOI: http://dx.doi.org/10.1016/j.phymed.2015. 04.002

Avoseh O, Oyedeji O, Rungqu P, Chungag BN, Oyedeji A. 2015. Cymbopogon Species; Ethnopharmacology, Phytochemistry and the Pharmacological Importance. Molecules, 20: 7438-7453. DOI: 10.3390/molecules20057438

Bassolé IHN, Meda AL, Bayala B, Obame LC, Ilboudo AJ, Franz C, Novak J, Nebié RC, Dicko MH. 2011. Chemical composition and antimicrobial activity of Cymbopogon citratus and Cymbopogon giganteus essential oils alone and in combination. Phytomedicine, 18: 10701074. DOI: 10.1016/j.phymed.2011. 05.009

Blanco MM, Costa CARA, Freire AO, Santos Jr. JG, Costa M. 2009. Neurobehavioral effect of essential oil of Cymbopogon citratus in mice. Phytomedicine, 16: 265 270. DOI: 10.1016/j.phymed.2007. 04.007

Bossou AD, Ahoussi E, Ruysbergh E, Adams An, Smagghe G, Kimpe N De, Avlessi F, Sohounhlouea DCK, Mangelinckx S. 2015. Characterization of volatile compounds from three Cymbopogon species and Eucalyptus citriodora from Benin and their insecticidal activities against Tribolium castaneum. Industrial Crops and Products, 76: 306-317. DOI: http://dx.doi.org/10.1016/j.indcrop.2015. 06.031

Briones MDCV, Hernández LR, Beltrán JÁG. 2015. Physicochemical and Antioxidant Properties of Cymbopogon citratus 
Essential Oil. Journal of Food Research, 4(3): DOI: $10.5539 /$ jfr.v4n3p36

Costa CARA, Bidinotto LT, Takahira RK, Salvadori DMF, Barbisan LF, Costa M. 2011. Cholesterol reduction and lack of genotoxic or toxic effects in mice after repeated 21-day oral intake of lemongrass (Cymbopogon citratus) essential oil. Food and Chemical Toxicology, 49: 2268-2272. DOI: 10.1016/j.fct.2011.06.025

Diop SM, Guèye MT, Ndiaye I, Ndiaye EHB, Diop MB, Heuskin S, Fauconnier ML, Lognay G. 2016. Chemical composition of essential oils and floral waters of Mentha longifolia (L.) Huds. from Senegal. American Journal of Essential Oils and Natural Products, 4(1): 46-49. DOI : http://www.essencejournal.com/ vol4/issue1/pdf/4-1-2.1.pdf

Fadli M, Pagès JM, Mezrioui NE, Abbad A, Hassani L. 2016. Artemisia herba-alba Asso and Cymbopogon citratus (DC.) Stapf essential oils and their capability to restore antibiotics efficacy. Industrial Crops and Products, 89: 399-404. DOI: http://dx.doi.org/10.1016/j.indcrop.2016. 05.039

Francisco V, Costa G, Figueirinha A, Marques C, Pereira P, Neves BM, Lopes MC, Rodríguez CG, Cruz MT, Batista MT. 2013. Anti-inflammatory activity of Cymbopogon citratus leaves infusion via proteasome and nuclear factor- $\mathrm{kB}$ path way inhibition: Contribution of chlorogenic acid. Journal of Ethnopharmacology, 148: 126-134. DOI: http://dx.doi.org/10.1016/j.jep. 2013.03.077

Guèye MT. 2012. Gestion intégrée des ravageurs de céréales et de légumineuses stockées au Sénégal par l'utilisation de substances issues de plantes. Thèse de doctorat en sciences agronomiques et ingénierie biologique, Gembloux Agro Bio-Tech, Université de Liège, Belgique, p. 216.

Hanaa ARM, Sallam YI, El-Leithy AS, Aly SE. 2012. Lemongrass (Cymbopogon citratus) essential oil as affected by drying methods. Annals of Agricultural Science, 57(2): 113-116. DOI: http://dx.doi.org/10.1016/j.aoas.2012.08. 004

Joulain D, König WA. 1998. The Atlas of Sesquiterpene Data Hydrocarbons. E.B.Verlag, Hamburg.

Kpoviessi S, Bero J, Agbani P, Gbaguidi F, Kpoviessi BK, Sinsin B, Accrombessi G, Frédérich M, Moudachirou M, Leclercq JQ. 2014. Chemical composition, cytotoxicity and in vitro antitrypanosomal and antiplasmodial activity of the essential oils of four Cymbopogon species from Benin. Journal of Ethnopharmacology, 151: 652-659. DOI: http://dx.doi.org/10.1016/ j.jep.2013.11.027

Leal WS, Uchida K. 1998. Application of GCEAD to the Determination of Mosquito Repellents Derived from a Plant, Cymbopogon citratus. J. Asia-Pacific Entomol., 1(2): 217-221. DOI: 10.1016/S1226-8615(08)60022-9

Maia MF, Moore SJ. 2011. Plant-based insect repellents: a review of their efficacy, development and testing. Malaria Journal, 10(1): S11. DOI: http://www.malariajournal.com/content/ 10/S1/S11

Naik MI, Fomda BA, Jaykumar E, Bhat JA. 2010. Antibacterial activity of lemongrass (Cymbopogon citratus) oil against some selected pathogenic bacterias. Asian Pacific Journal of Tropical Medicine, 3(7): 535-538. DOI: 
https://doi.org/10.1016/S1995-7645

(10)60129-0

Ngom S, Diop M, Mbengue M, Faye F, Kornprobst JM, Samb A. 2014. Composition chimique et propriétés antibactériennes des huiles essentielles d'Ocimum basilicum et d'Hyptis suaveolens (L.) Poit récoltés dans la région de Dakar au Sénégal. Afrique SCIENCE, 10(4): 109-117. DOI : http://www.afriquescience.info/documen t.php?id=4022

Smadja J. 2009. Les huiles essentielles. Colloque GP3A-Tananarive.

Soonwera M, Phasomkusolsil S. 2015. Efficacy of Thai herbal essential oils as green repellent against mosquito vectors. Acta Tropica, 142, 127-130. DOI: http://dx.doi.org/10.1016/j.actatropica.20 14.11 .010

Sutour S. 2010. Etude de la composition chimique d'huiles essentielles et d'extraits de menthes de Corse et de Kumquats. Thèse de Doctorat de Chimie Organique et Analytique, Faculté des Sciences et Techniques, Université de Corse Pascal Paoli, p. 76-84.

WHO. 2015. Malaria report, WHO, http://www.who.int/malaria/publications/ country-profiles/profile_sen_en.

pdf?ua $=1$ Consulted December 5th, 2016 . 